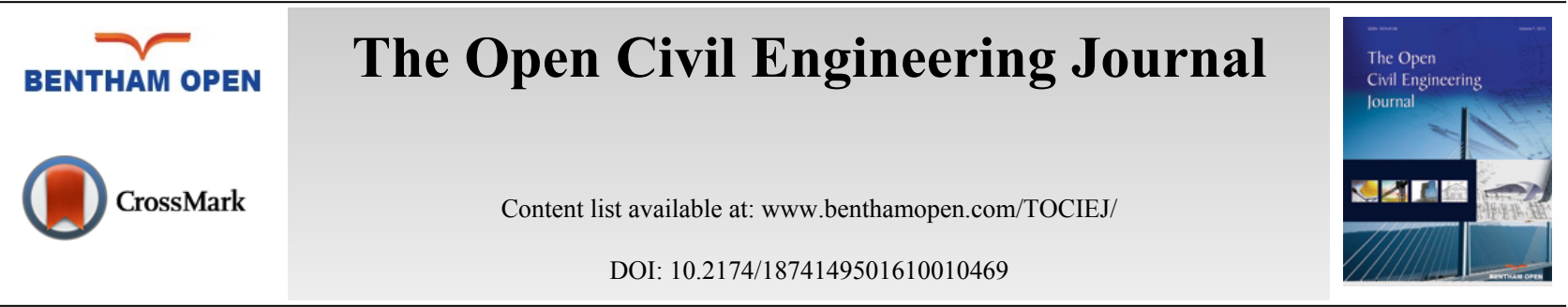

RESEARCH ARTICLE

\title{
Main Reasons of Structural Wall Collapse in Chile 2010 and New Zealand 2011 - Implications For Ecuador
}

\author{
Maria Cristina Avalos Aguilar , Ana Gabriela Haro and Pablo Caiza Sánchez \\ Universidad de las Fuerzas Armadas ESPE, Universidad de las Fuerzas Armadas ESPE, Universidad de las Fuerzas \\ Armadas ESPE, Ecuador
}

\begin{abstract}
Previous works on the earthquakes of Chile 2010 and New Zealand 2011 indicate regular behavior of reinforced concrete buildings with structural walls. However, some buildings suffered significant damage associated with global or local collapse due to diagonal cracking and flexural-compression failure. Structural walls located at the ground floor presented tension-compression failure was probably provoked by high axial forces at the walls extreme ends which could cause this failure in places where there is a lack of bracing and confinement.

The purpose of this paper is to analyze the behavior of the reinforced concrete structural wall buildings that failed in the mentioned earthquakes, and identify some of the main reasons that caused the damage as an attempt to improve engineering practices in Ecuador to prevent catastrophic events.
\end{abstract}

Keywords: 2010 Chile earthquake, Earthquake engineering in Ecuador, Structural walls, 2011 New Zealand earthquake.

\section{INTRODUCTION}

Chile is a South American country located between the Andes Mountains and the Pacific Coast in the southern part of the Continent. Chile is a volcanic and seismic zone due to subduction of the Nazca and Antarctic Plates in the South America Plate. Chile suffered a shocking 8.8-magnitude earthquake on Sunday, 27 February, 2010 at 03:34 local time which lasted 2 minutes and 45 seconds. The epicenter was located at a $35 \mathrm{Km}$ depth, about $3 \mathrm{Km}$ off the coast of Pelluhue in the Maule Region. At least 523 people died, 12 were injured and 800,000 were relocated. Regarding the damaged buildings, 370 houses, 4,013 schools and 79 hospitals presented failures or collapsed after the tremor. The tsunami at Valparaiso-Concepcion-Temuco was about 261 centimeters over the ocean level. The event was recognized as the strongest strike registered since the 9.5-magnitude earthquake on May 22, 1960 [1].

Other similar earthquakes have occurred in the Pacific Coast of South America, such as the 7.5-magnitude earthquake on April 9, 1902, which killed almost 2,000 people in Quetzaltenango and San Marcos, Guatemala. On January 31, 1906, an 8.8-magnitude earthquake struck off the coast of Esmeraldas, in Ecuador where 1,000 people died. Tsunami waves as high as 16 feet (4.9 meters) were observed. This proves the likelihood of strong earthquakes all along the Pacific Coast.

New Zealand is an island country located in the southwestern Pacific Ocean, characterized for its volcanic and seismic activity, and geothermal areas due to its position on the boundary of the Pacific Plate and Australian Plate. A 6.3-magnitude earthquake occurred in New Zealand on Monday, February 21, 2011 at 23:51:43 UTC. at a 5.9 Km depth, in the Canterbury Region in the eastern center part of New Zealand's South Island, 2 kilometers west to the port town of Lyttelton and $10 \mathrm{Km}$ southwest to the center of Christchurch, the second most populous city of the country. Regarding the effects of the event, 181 people died, 1,500 resulted injured, and 100,000 buildings were damaged; $16 \%$

* Address correspondence to this author at the "Universidad de las Fuerzas Armadas ESPE ”, Av. General Rumiñahui s/n, Sangolqui, Ecuador; Tel: 593-998571383; E-mail: mcavalos@espe.edu.ec 
of 833 buildings, which were constructed with structural walls, failed. The greater damage happened at Christchurch-Lyttleton where liquefaction and landslides were observed [2].

The Christchurch earthquake was part of the 7.1 Mw earthquake that occurred on September 3, 2010, in Darfield, 40 kilometers west of Christchurch. It involved oblique-thrust faulting at the eastern most limit of previous aftershocks and like the main shock itself is broadly associated with regional plate boundary deformation as the Pacific and Australia plates interacting in the central South Island, New Zealand [1]. After the earthquake, $41 \%$ of the structures built with structural walls before 1970s presented acceptable conditions with minor damage, $44 \%$ of them suffered small damage, and $15 \%$ of the structures presented significant damage. In contrast, $57 \%$ of the structures built in the 1980 s were not affected, $32 \%$ presented minor damage and $11 \%$ reported significant damage [2].

Currently, the trend is the construction of higher and stiffer irregular buildings with RC structural walls. However, the 2010 Chile and 2011 New Zealand earthquakes have shown that this typology presented important structural problems. Based on the events mentioned above, this paper focuses on the lessons learned through the reported failure modes on RC structural walls, usually referred as shear walls; however, the name is not considered appropriate since according to design and construction Codes, they must resist combinations of shear, moment and axial forces accompanied with high ground shakings without stiffness or strength losses [3, 4].

\section{NEW ZEALAND STRUCTURAL WALLS BEHAVIOR}

Four cases have been selected to develop the following analysis. The four RC buildings represent the most severe damage observed during the Christchurch earthquake:

The collapse produced in 6-storey CTV (Canterbury Television) building produced about $63.5 \%$ of all the reported deaths. The structure presented regularity in plan with 4 axes in $\mathrm{Y}$ direction and 6 axes in $\mathrm{X}$ direction, with two walls: the North Core around the stairs and the lift and the South Wall in the Southern part of the building. In the western part there was a masonry wall between the columns and the beams from the first three floors, as shown in Fig. (1). The center of rigidity was away from the center of mass. The slabs separated from the North Core and large displacements caused critical columns to fail.

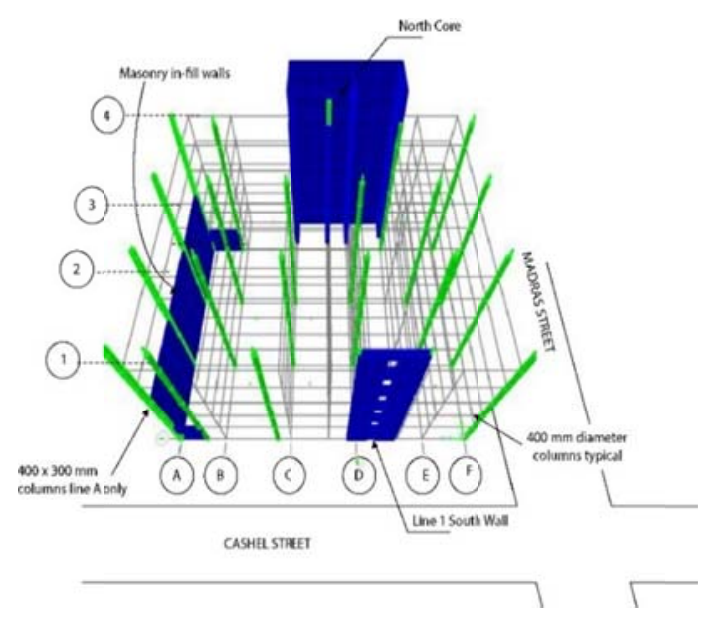

Fig. (1). CTV Building, Structural walls location [5].

The five-storeys Pyne Gould Corporation building constructed in 1960 suffered total collapse resulting in 18 deaths and 28 people injured rescued from the debris. It had regular horizontal area, with the same number of resistant lines in $\mathrm{X}$ direction and $\mathrm{Y}$ direction. The RC structural wall was $203 \mathrm{~mm}$ thick. The central walls and the cantilever of the first floor present eccentricity as shown in Fig. (2). The joints between the columns and the beams, and the connections between the structural wall and the slabs, failed causing the floors to fall down. 


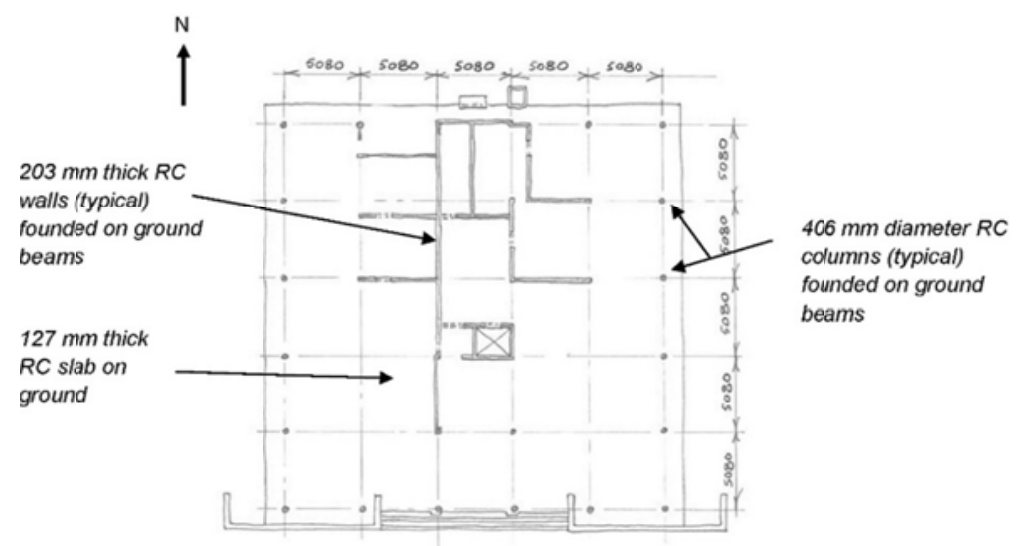

$R C=$ reinforced concrete

Fig. (2). Ground Level Plan of Pyne Gould Corporation [6].

The 22-storeys Grand Chancellor Hotel building did not report deaths during this earthquake; it was built between 1985 and 1988 with horizontal and vertical irregularities as shown, (Fig. 3). The upper tower relied on a reinforced concrete frame for seismic resistance, and the lower tower relied on a reinforced concrete structural wall. The earthquake caused the rupture of the structural wall in the south east corner of the Hotel, which produced a 0.8 meters deformation, approximately, and a horizontal deflection of 1.3 meters at the top of the Hotel. The loading aspect ratio of the wall was high, and during the ground motion it attracted additional loading. Flexural actions concentrated these axial loads at one end of the wall, and unconfined concrete is very likely to suffer brittle compression failure [7]. This building was demolished after the earthquake.

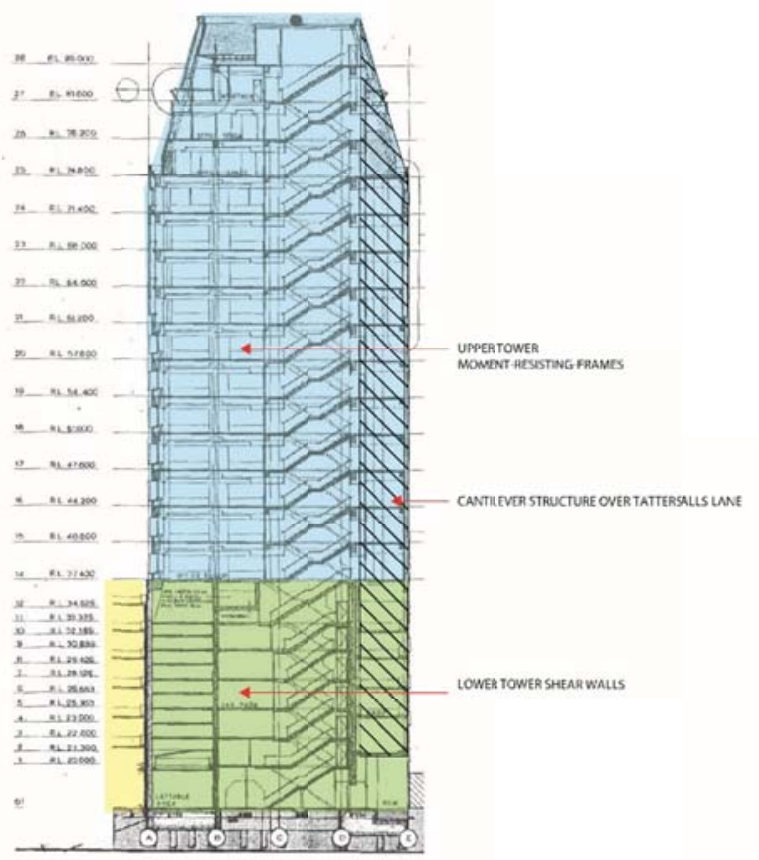

Fig. (3). Vertical Irregularity of Grand Chancellor Hotel [7].

The Forsyth Barr Building was a 18 storeys high, which reported minor damage compared to the three structures mentioned above. Before the Christchurch earthquake, Forsyth Barr building presented some structural problems which were the origin of the damage during the tremor. Built in 1988, founded on a shallow raft, the floors extend beyond the footprint of the tower to form a podium on the south and east sides. Failure of a podium column was reported after the 
earthquake. The main damage associated with this building is the staircase collapse since occupants were trapped until they could be rescued. The staircases collapsed due to high drift demands. Floor plan and location is shown in Fig. (4).

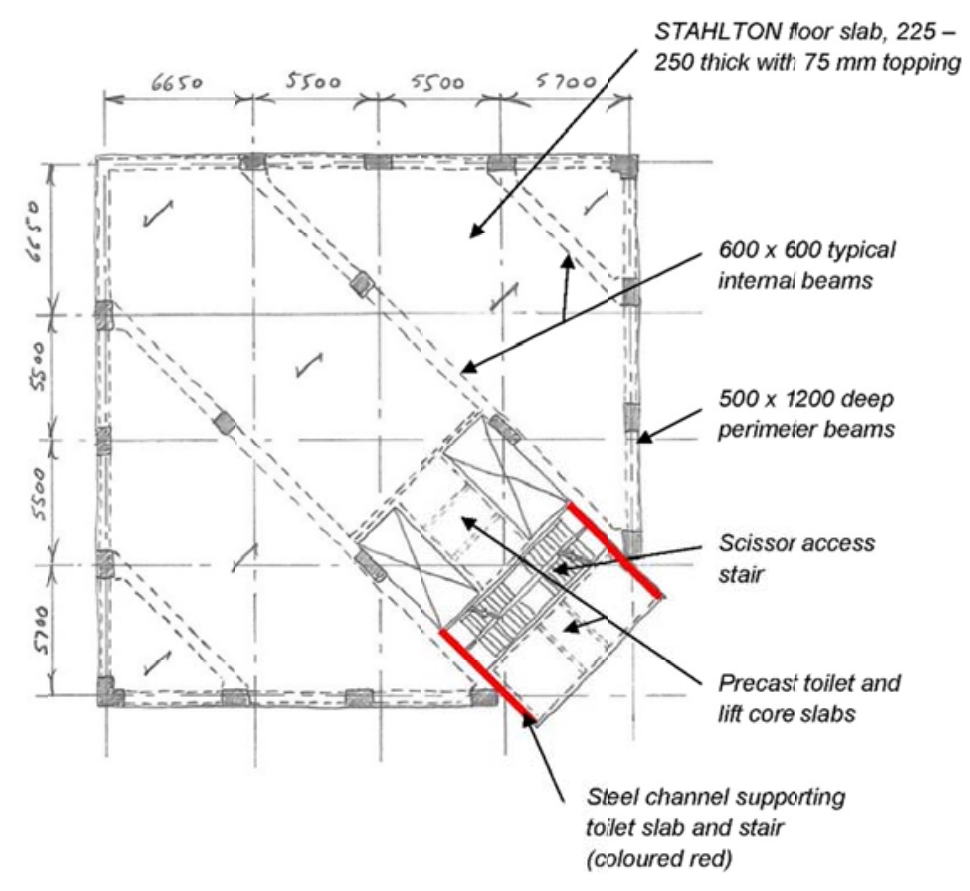

Fig. (4). Floor Plan and location of the scissor stairs of Forsyth Barr Building [8].

\subsection{High Ground Accelerations and Building Codes}

One of the factors that caused these structures to fail was the high ground accelerations. Vertical accelerations reported in New Zealand were four times higher than the Japan Earthquake on March, 11, 2011 Tohoku, 9 Mw [6]. Fig. (5) shows the reached accelerations of $2.2 \mathrm{~g}$ sited at $6 \mathrm{Km}$ from the epicenter and $1.8 \mathrm{~g}$ in Christchurch.

For example, in the Hotel Grand Chancellor the ground shaking in the vertical direction generated amplified dynamic response from either the upper floor cantilever or the cantilever transfer beams. The current construction code did not consider vertical accelerations at cantilevers, then those elements were prone to fail [10].

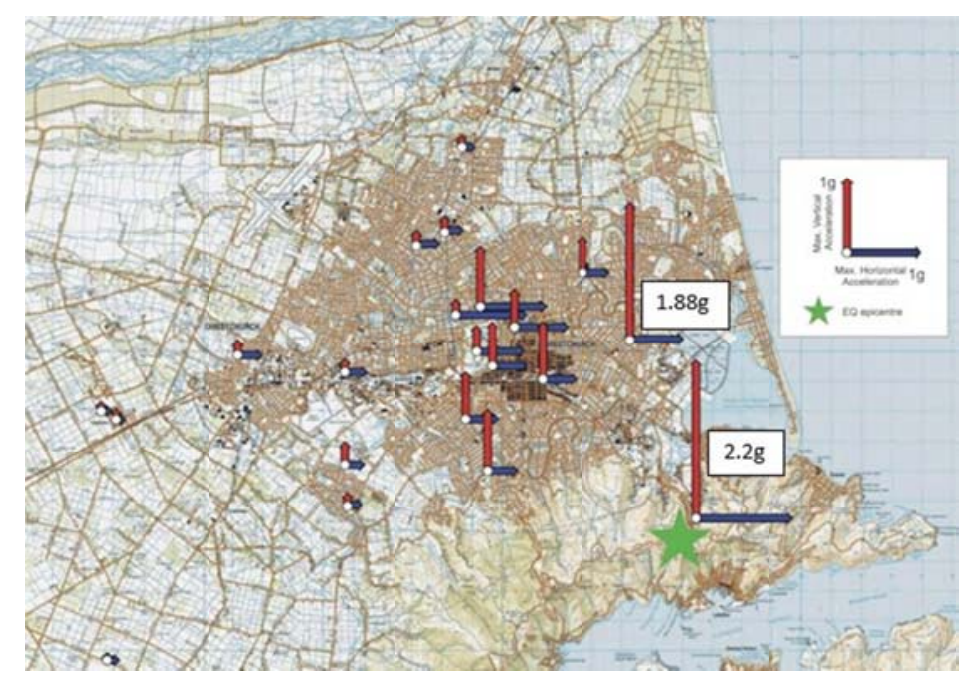

Fig. (5). Accelerations at the Center of the City [9].

Another fact to analyze is the New Zealand Construction Code, in 1965 the designing standards did not include the 
concept of ductility and its spectral acceleration was lower. Progressively, the standards had been improved including ductilities about 4 but still it was not enough for the Christchurch Earthquake accelerations [11]. The last standards by that time were the 2010 Building Code that considered a return period of 2500 years, but it was not adequate since the range of the spectral accelerations of the earthquake was higher than the spectral accelerations provided in the Code.

Fig. (6) depicts plots of spectral acceleration against the period. These accelerations versus periods are used to identify how buildings of different types and sizes responded to the earthquake. The vertical axis estimated the maximum acceleration of the building according to the specific ground motions. The horizontal axis represent the period of vibration of a building which increases depending on the height and building type. For example, the low-rise buildings have shorter periods, and high-rise buildings have longer periods. According to this, the PGC Building period was 0.7 seconds, and the Forsyth Barr Building was 2.4 seconds.

In addition, Fig. (6) provides a comparison of the Christchurch Earthquake demands; the blue line represents the design level of a 500-year event for the modern buildings, this curve assumes that the buildings respond elastically. The yellow line represents the design level standards of 1984 and 1976 according to their Codes. These correspond to the equivalent elastic response values, so that they are compatible with the accelerations for the ground motion records. According to the Standards, it was allowed to reduce the accelerations if the building had a ductile design. The green curve characterizes the design requirement for the Construction Code of 1965. The solid line represents the performance of the buildings with this Code in which the full ductility is achieved. The navy line correspond to buildings constructed with the 1965 standards, which caused changes in the levels of ductility to be achieved.

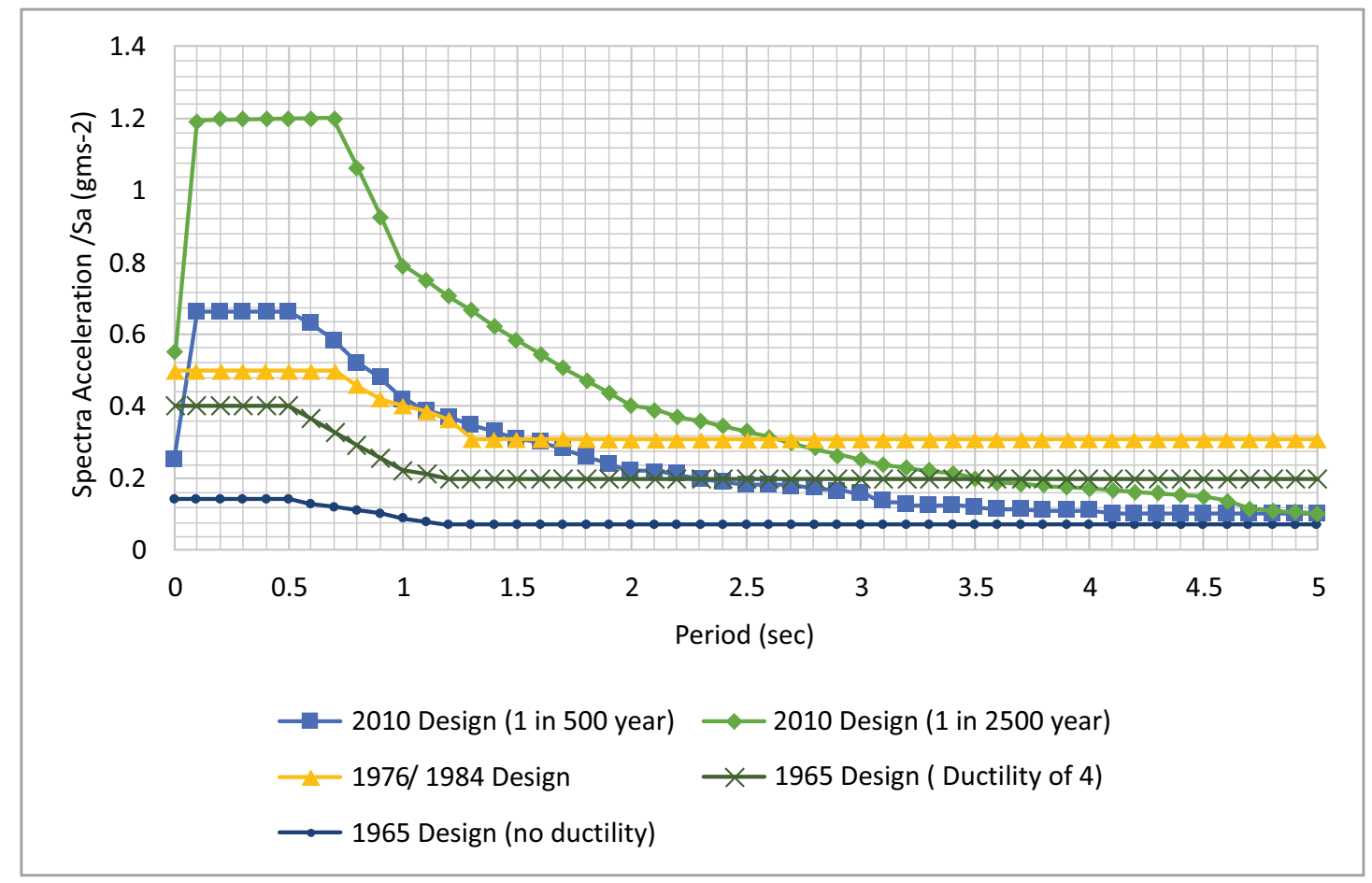

Fig. (6). Design versus Demand, Elaborated by Maria Cristina Avalos (Based on New Zealand Department of Building and Housing, 2012).

In the case of the CTV Building after the Darfield Earthquake the columns presented cracks due to the non-ductile reinforcement distribution. It was less than the minimum required reinforcement for shear in circular columns. Additionally, large portions of concrete cover, low concrete compression strengths critical columns, and lack of ductility in the beam-columns joints, which provoke fragile columns, were reported. The forces and displacements produced during the $6.3 \mathrm{Mw}$ earthquake affected the critical columns and made them overloaded. Consequently, it provoked failure on the contiguous slabs [5]. 


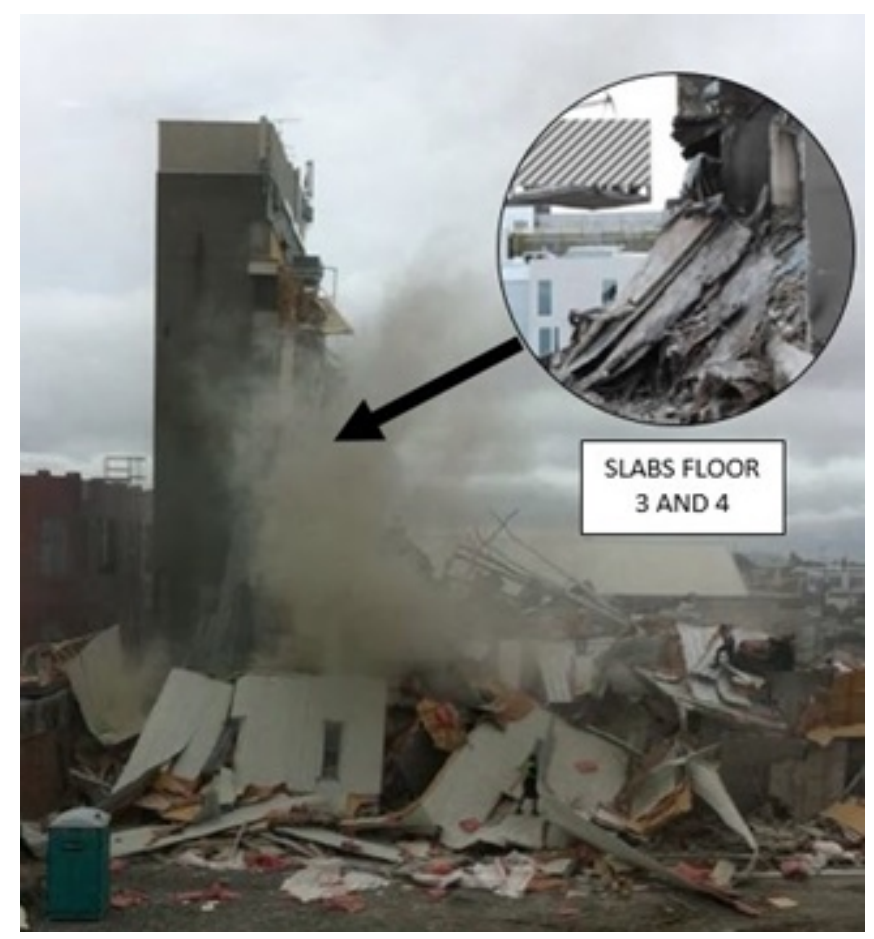

Fig. (7). North Core after collapse [5].

As well as the CTV Building, the PGC Building did not present a ductile response, because of the year of construction (1960), and the walls were designed to support loads and accelerations established from the 1960s. If a comparison is established between the Code NZS 1960 and the NZS 3010:2006, NZS 1170, the older one only would fulfill 30 to $40 \%$ of the new one [11].

\subsection{Low quality control and design of the structure}

An additional factor which caused some buildings to collapse, was the low quality control by the time the buildings were constructed. Even though in some buildings the structural design and specifications were appropriate, they were not followed at the moment of construction.

For the CTV Building case, the tensile properties of the reinforcing bars included in the walls resulted similar with average values of $16.8 \%$ for the uniform elongation at maximum force and $448 \mathrm{MPa}$ for the yield stress. It was reported that some bars underwent a level of plastic work hardening. The concrete in the wall was 33.8 MPa. According to specifications it had to be $35 \mathrm{MPa}$. The same occurred in other structural elements where 26 of 123 columns were tested. Based on Hyland results, columns presented a mean of $27.4 \mathrm{MPa}$ [11].

Another fact to be considered is the usage of the building during its service life. The CTV building had experienced different functions like being a hospital, an education center, a library and office building, so the live load had changed causing extra loads that were not included in the original design. Table 1 shows the live loads according to NZS4203:1984. In the distributed load there was no difference between school classrooms and hospital bedrooms, but in the concentrated load there is a high difference. Considering the hospital had a boiler room, the live load changed abruptly compared with an education center and offices. The collapse of the CTV building was attributed to the failure of one of the structural walls. The slabs fell down as a consequence of damaged columns. Only the north core remained as shown in Fig. (7).

Table 1. Live Load for CTV according to NZS4203:1984 [12].

\begin{tabular}{|l|c|c|c|}
\hline \multirow{2}{*}{ Use } & \multicolumn{2}{c|}{ Live Load } \\
\cline { 3 - 4 } & Distributed [KPa] & Concentrate [kN] \\
\hline \multirow{2}{*}{ Education Center } & Classrooms & 3 & 2.7 \\
\cline { 2 - 4 } & Library & 3 & 2.7 \\
\hline
\end{tabular}


(Table 1) contd.....

\begin{tabular}{|c|c|c|c|}
\hline \multicolumn{2}{|c|}{ Use } & \multicolumn{2}{c|}{ Live Load } \\
\cline { 3 - 4 } & & Distributed [KPa] & Concentrate [kN] \\
\hline Offices & General Use & 2.5 & 2.7 \\
\hline \multirow{2}{*}{ Hospital } & Bedrooms & 3 & 1.8 \\
\cline { 2 - 4 } & Boiler rooms & 5 & \\
\hline
\end{tabular}

Irregularities in the structures provoked their center of mass and center of stiffness to be separated. In the case of the PCG Building, the vertical and horizontal irregularities caused vulnerabilities because of the lack of continuity in the walls between the storeys, which reduced the vertical load resistance. The material used for steel reinforcement was composed by higher percentages of Tin (Sn) and Phosphorus (P) than the supposed, causing crystallization of the element, less ductility and fragile behavior. These percentages were according to the construction code in that time; however, some experiments had reported P percentages close to $0.04 \%$. After the collapse of the building some tests carried out on the reinforcement bars, showed $\mathrm{P}$ percentages around $0.05 \%$ and $0.066 \%$

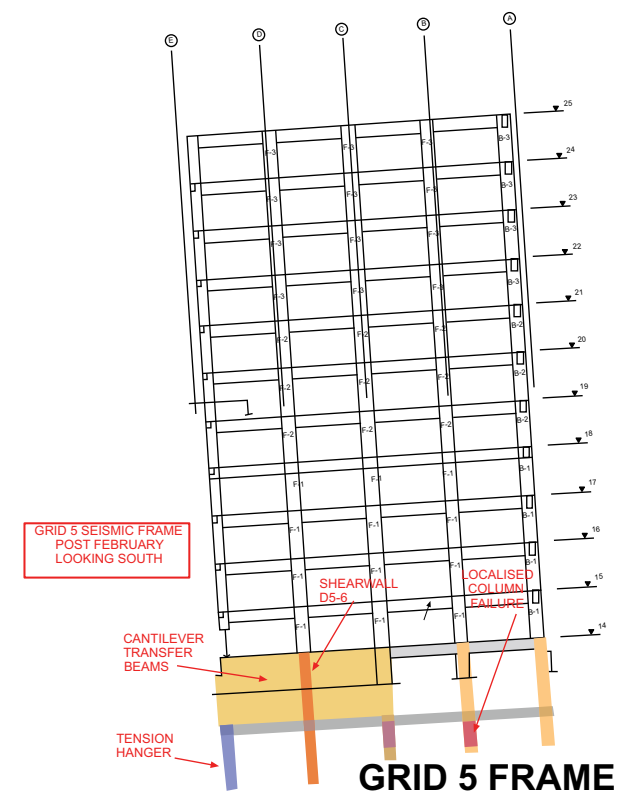

Fig. (8). Collapse of Hotel Grand Chancellor [7].

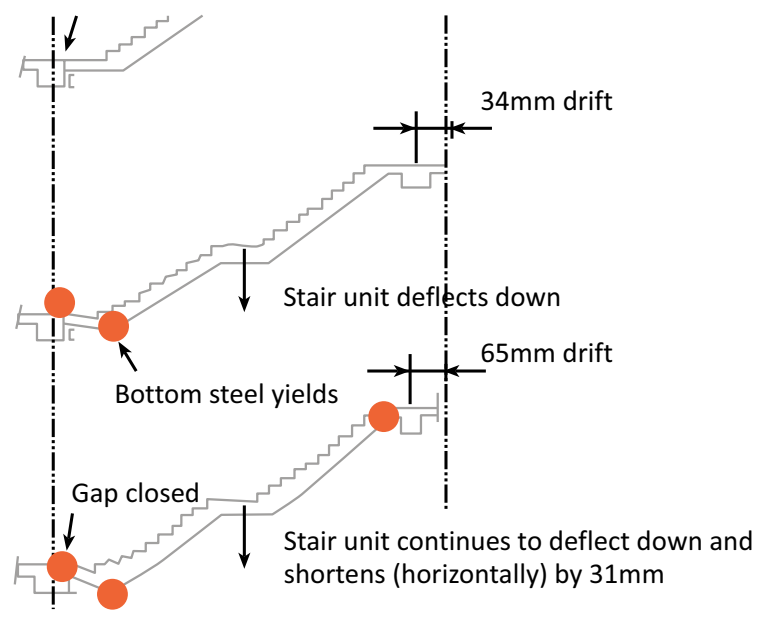

Fig. (9). Stairs of Forsyth Barr [8].

In the Hotel Grand Chancellor one of its walls failed due to compression because of the high axial load ratios combined with low levels of reinforcement. This structural wall supported the weight of 8 floors and the lateral seismic loads. As result, the building dropped by approximately $800 \mathrm{~mm}$ and a horizontally deflection of $1,300 \mathrm{~mm}$ was registered at the top of it. Fig. (8) shows how Hotel Grand Chancellor failed. The building showed lack of robustness 
and resilience of the wall, and was not able to support loads in excess. The longitudinal reinforcement and confinement were not appropriate to support axial loads, then the base of one of the structural walls failed.

In the case of The Forsyth Barr the stairs shown in Fig. (9) were the only one damaged due to compression, bending downward and yield in its reinforcement. The construction tolerances decreased the required horizontal displacement. The seismic movement gap, considered also as expansion joint, at the base was too small to avoid compressive actions. Some materials were found in this gap, which could have exacerbated the compression forces. The stairs failed from the ground level all through the 14 and 15 levels. Investigations concluded the stairs must be designed to maintain their structural integrity. While scissor stairs are used, a proper design should be done and seismic gaps must be clear, and not reduced. Scissor Stairs are two stairs provided within a single shaft and separated by a light weight partition running between and in all the height of the stairs. Fig (10) shows the stairs after collapse. The maximum inter storey drift for this building predicted at the moment of the earthquake exceeded the required at the time of design by about $80 \%$; it also exceeded the actual Code by about $60 \%[8]$.

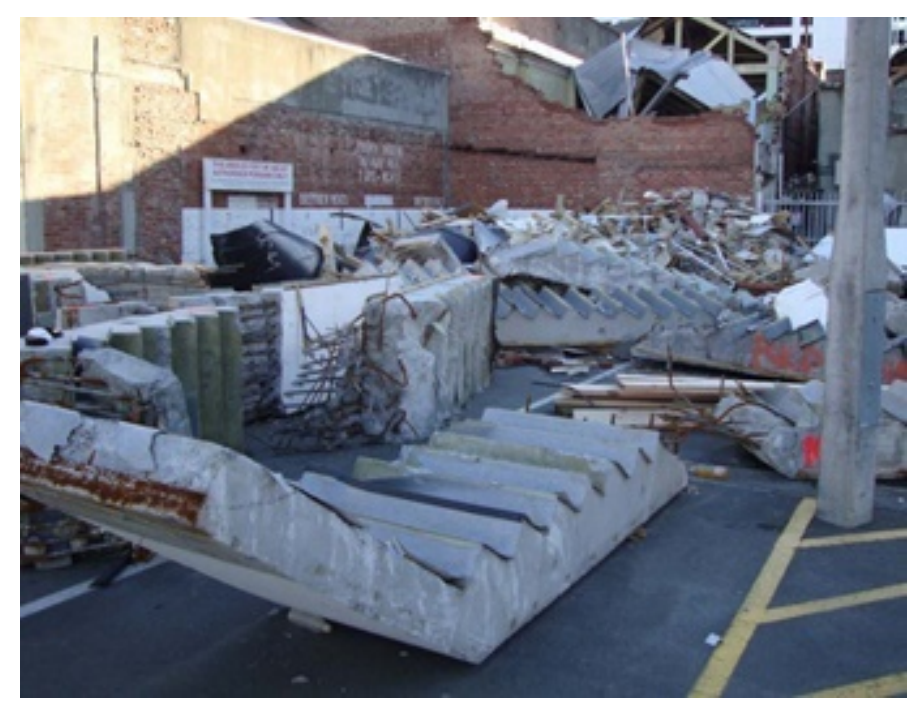

Fig. (10). Collapse of the Stairs of Forsyth Barr [8].

Table 2, presents a recompilation of problems presented in the buildings after New Zealand Earthquake.

Table 2. Compilation of problems of New Zealand Building.

\begin{tabular}{|c|c|}
\hline Problem & Building \\
\hline Lack of Ductility & CTV Building, PGA Building \\
\hline Concrete Strength & CTV Building, PGA building \\
\hline Lack of symmetry & CTV Building, Hotel Grand Chancellor \\
\hline Overload & CTV Building \\
\hline Reinforcement Problems & PGA Building, Hotel Grand Chancellor, Forsyth Barr \\
\hline
\end{tabular}

\section{CHILE STRUCTURAL WALLS BEHAVIOR}

During the 2010 Chile earthquake, more than one hundred buildings were damaged. The most common damage was due to compression failure of thin walls in the lower levels of the buildings. Buckling of compression reinforcement after concrete crushing and brittle failures were also observed at wall boundaries influenced by the level of axial stresses, large displacements demands, and lack of symmetry [13].

According to this research $2.5 \%$ of the modern engineering constructions built after 1985 suffered damage, only 4 buildings suffered complete collapse and about 50 suffered damage beyond repair [14].

\subsection{Flexural Compression Failure}

An 18-storey building in Santiago, with a floor plan about $14 \times 37 \mathrm{~m}^{2}$, includes two structural longitudinal walls 200 $\mathrm{mm}$ thick. On both sides of a $1.6 \mathrm{~m}$ wide central corridor, there are seven transverse walls, $200 \mathrm{~mm}$ and $150 \mathrm{~mm}$ thick. Three structural walls failed in flexural compression, causing the building to drop down $75 \mathrm{~mm}$ and a permanent drift of 
$0.44 \%$. The thicknesses of these walls were $150 \mathrm{~mm}$ and $200 \mathrm{~mm}$ with two horizontal reinforcement layers. Compression strains less than 0.0015 were reported by Adebar and Lorzadeh, 2012 [15]. Fig. (11) ilustrates how the failure of the 18-storey building was produced at the ground level.

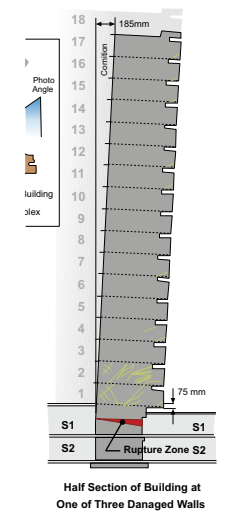

Fig. (11). 18 storey building failure [15].

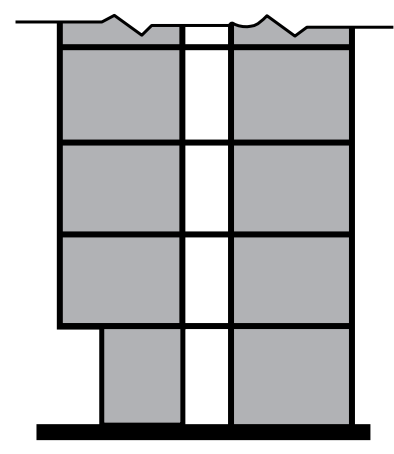

Fig. (12). Alto Rio Condominium irregularity [14].

\subsection{Tension Compression Failure}

Central Park building in Chile, is a 19-storey reinforced structural wall building that suffered tension - compression failure in one of its walls and columns, also this provoked buckling of the transversal wall where the main bars presented lack of seismic hooks, deficient reinforcement due to small bar diameters, and large spaces between the transversal reinforcement as shown in Fig. (13) [16].
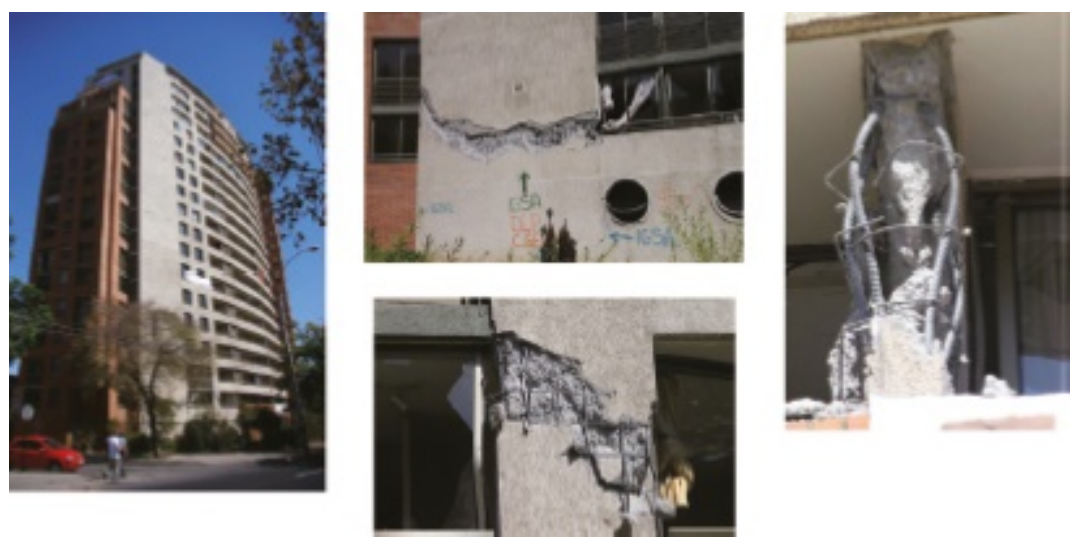

Fig. (13). Tension Compression Failure in Central Park Building [16].

\subsection{Plan and Elevation Irregularities}

Some of the buildings that failed due to lack of regularity and symmetry followed the regulations from the Construction Seismic Code of Chile 1996, which did not provide restriction on structural irregularities, and 
consequently many buildings were constructed with plan and elevation irregularities.

In addition, modern buildings failed. The 15-storey Alto Rio Condominium located in the city of Conception was built on soft alluvium soil and included reinforced concrete walls with an offset at the first level, as illustrated in Fig. (12). It presented slender walls, and lack of confinement at the boundary elements. This irregularity would have increased compressive stresses in the first level so the wall could trigger, making the structure to collapse [14].

The 21-storey high Torre O'Higgins office building, suffered torsional eccentricity due to the structural walls located at the back of the building. The irregularities detected in this building made the force and deformation demands to be concentrated at the front of the building. Torsional behavior due to an earthquake, is separated in "inherent torsion" and "accidental torsion", in this case because of the asymmetric geometry of the building is classified as "inherent torsion" [17].

In Conception another irregularity problem was detected in the 13-storey Plaza Rio residential building, composed with one L-shaped wall, consisted of two buildings with a seismic joint. Some of its walls were discontinuous including the first storey where the columns resisted the walls creating a soft storey. The walls were slender with light reinforcement and no confinement reinforcement, producing buckling in the longitudinal bars.

\section{IMPLICATIONS FOR ECUADORIAN ENGINEERING PRACTICES}

Ecuador has suffered about four 6-magnitude earthquakes or greater between 1906 and 2007 which caused 6,050 deaths [18]. Recently, 5-magnitude earthquakes [19] have demonstrated the necessity of improvements in our Reinforced Concrete systems such as structural walls. Reinforced concrete structural walls have been used with success in seismic design of multistory buildings. This system exhibits high levels of strength and ductility under ultimate loads when they are designed in a proper manner [20]. The disadvantage could be the lack of experience and practice in building walls, and the direct construction cost.

It is a fact that the implementation of structural walls in Ecuador can reduce relative displacements between floors. As a consequence, damage of structural and nonstructural elements would be reduced, preventing in this way the occurance of deadly catastrofies. Protection against unnecessary damage during earthquakes of low intensity, reduction of structural damage in less frequent and more intense seismic hazards are also achivied through ductily RC strcutral walls system. Evidently, to accomplish this purpose it is imperative the aplication of appropriate design and assessment procedures.

After all the research done related to structural walls, Ecuador should avoid the lack of ductility which was the main cause of collapse for some buildings. Building projects must start considering the possible problems that some elevation and plan irregularities could cause when an earthquake occurs. Furthermore, structural details usually are misunderstood by construction workers implying the omission of critical design parameters and consequently the reduction of ductility.

New analysis methods must be included in the structural wall design in the country, such as nonlinear static analysis used for the evaluation of the seismic performance of structures, better known as the pushover analysis method that can calculate the seismic forces and deformations demand through the redistribution of internal forces in the nonlinear regime [21]. Alternatively, performance-based seismic engineering (PBSE) constitutes a promising design philosophy which has being incorporated in modern guidelines and codes, including the Ecuadorian Construction Code.

\section{CONCLUSION}

This paper presents a summarized analysis of the behavior of RC structural walls in different investigations and field observations made after the 2010 Chile and 2011 New Zealand earthquakes:

1. With respect to New Zealand Structures, one of the factors that influenced the massive damage in some structures was the regulations established in previous Construction Codes (1960-1980), where the effect of highest axial loads, the lack of ductility parameters and reinforcement were omitted. Consequently, drifts and displacements increased, and low quality control at the time of construction was detected.

2. The longer the duration of an earthquake are the greater effects on buildings, especially in those without seismic resistant structural systems.

3. The seismic hazard coefficient or building design must be re-evaluated considering all the occurred events.

4. Around the 1960 s the constructive method for walls usually was the usage of reinforcing steel in a central layer 
without confining reinforcement, which indicates that the structural walls were not considered important in their reinforcement at that time. In Ecuador is highly recommended to ovoid the construction of this type of nonductile RC walls.

5. Some of the structural problems presented in Chile buildings were associated with the thickness of structural walls around $200 \mathrm{~mm}$. This was some of the main causes for structural collapses and should be considered in future Constructions Codes. The aspects ratios were not only a problem of the Construction Code of Chile, but also of the Canadian Code.

Finally, it is mandatory to improve the design codes and construction methods in countries that are prone to earthquakes, especially on those surrounding the Ring of Fire as Ecuador. In addition, quality control should be implemented during construction procedures to warranty reinforcement detailing is implemented as designed.

\section{CONFLICT OF INTEREST}

Declared none.

\section{ACKNOWLEDGEMENTS}

The author thanks to Ph.D. Pablo Caiza and Ph.D. Candidate Ana Gabriela Haro for their support in all the process of this work, their patient, enthusiasm and faith in me. Thanks to the "Universidad de las Fuerzas Armadas ESPE" that gives me the tools to successfully complete this paper.

\section{REFERENCES}

[1] "United States Geological Survey, "USGS", Science for a Changing World, Earthquakes Hazards Program,". [Online] Available: http://earthquake.usgs.gov/aboutus/, 2010 [Accessed 2015]

[2] W. Yuen Kam, and S. Pampanin, In: General Building Performance in the Christchurch CBD: A Contextual Report, Canterbury, London, 2011.

[3] J. P. Moehle, T. Ghodsi, J. D. Hooper, D. C. Fields, and R. Gedhada, "Seismic design of cast-in-place concrete special structural walls and coupling beams A guide for practicing engineers", NEHRP Seismic Design Technical Brief No. 6, 2011.

[4] T. Paulay, and M.J. Priestley, Seismic Design of Reinforced Concrete and Masonry Buildings., John Wiley and Sons: New York, 1992. [http://dx.doi.org/10.1002/9780470172841]

[5] C. Hyland, and A. Smith, CTV Building Collaps Investigation, Canterbury Earthquakes Royal Commission: New Zeland, 2012.

[6] Beca Carter Hollings \& Ferner Ltd (Beca), Investigation into the Collapse of the Pyne Gould Corporation Building on $22^{\text {nd }}$ February, 2011 2011

[7] Dunning Thornthon Consultants Ltd., Report on the Structural Performance of the Hotel Grand Chancellor in Earthquake of 22 ${ }^{\text {nd }}$ Febraury, New Zealand, 2011.

[8] Beca Carter Hollings \& Ferner Ltd (Beca), Investigation into the Collapse of the Forsyth Barr Building Stairs on $22^{\text {nd }}$ February 2011 Prepared for Department of Building and Housing (DBH)," Beca, 2011

[9] C. Hyland, and A. Smith, "GNS Science", Scientists Find Rare Mix of Factors Exacerbated the Christchurch Quake," 17 Marzo 2011. [Online] Available: http://www.gns.cri.nz/Home/News-and-Events/Media-Releases/Multiple-factors, [Accessed 2015]

[10] W. T. Holmes, Review For Royal Commision, Canterbury Earthquakes Royal Commission: New Zeland, 2012.

[11] New Zealand Department of Building and Housing, Structural Performance of Christchurch CBD Buildings in the 22 February 2011 Aftershock, New Zealand Department of Building and Housing: Christchurch, 2011

[12] General Structural Design and Design Loading for Buildings, Standards New Zealand: New Zeland, 1992.

[13] J. W. Wallace, "Behavior, design, and modeling of structural walls and coupling beams - lessons from recent laboratory tests and earthquakes", Int. J. Concr. Strut. Mater., vol. 6, no. 1, pp. 3-18, 2012.

[14] M. Saatcioglu, D. Palermo, A. Ghobarah, P.C. Sherstobitoff, D. Mitchel, R. Simpson, P. Adebar, Tremblay C Ventura, and H. Hong, "Performance of reinforced concrete buildings during the 27 February 2010 Maule (Chile) earthquake", Can. J. Civil Eng., vol. 40, no. 8, pp. 693-710, 2013. [July 26, 2013].

[15] P. C. P. A. J. Sherstobitoff, "Analysis and repair of an earthquake-damaged high-rise building in santiago, chile", In: $15^{\text {th }}$ World Conference on Earthquake Engineering, 24-28 September, vol. 20. Lisbon: Portugal, 2012, p. 10.

[16] F. Naeim, M. Lew, L.D. Carpenter, N.F. Youssef, and F. Rojas, "Performance of tall buildings in Santiago, Chile during the 27 February 2010 offshore Maule, Chile earthquake", Struct. Des. Tall Spec. Build., vol. 20, pp. 1-16, 2010.

[17] D. J. DeBock, A. B. Liel, C. B. Hase, J. D. Hooper, and R. A. J. Henige, "Importance of seismic design accidental torsion requirements for building collapse capacity", Earthq. Eng. Struct. Dyn., vol. 43, pp. 831-850, 2013. 
[18] "Earthquake Engineering Research Institute", Learning from Earthquakes Ecuador. [Online] Available: https:/www.eeri.org/category/ learning-from-earthquakes/ecuador/. [Accessed 2015]

[19] "Earthquake Track", Recent Earthquake Near Ecuador Recent Earthquake Near Ecuador. [Online] Available: http://earthquaketrack.com/p/ ecuador/recent., 2015

[20] Y.H. Chai, and D.T. Elayer, "Lateral stability of reinforced concrete columns under axial reversed cyclic tension and compression", $A C I$ Struct. J., vol. 96, no. 5, pp. 780-789, 1999.

[21] N. Valoroso, F. Marmo, and S. Sessa, "Limit state analysis of reinforced shear walls", Eng Struct., vol. 61, pp. 127-139, 2014. [http://dx.doi.org/10.1016/j.engstruct.2013.12.032]

\section{C) Aguilar et al.; Licensee Bentham Open}

This is an open access article licensed under the terms of the Creative Commons Attribution-Non-Commercial 4.0 International Public License (CC BY-NC 4.0) (https://creativecommons.org/licenses/by-nc/4.0/legalcode), which permits unrestricted, non-commercial use, distribution and reproduction in any medium, provided the work is properly cited. 